\title{
ANALYSIS OF OUTRIGGER SYSTEM FOR TALL VERTICAL IRREGULARITES STRUCTURES SUBJECTED TO LATERAL LOADS
}

\author{
Shivacharan $\mathbf{k}^{1}$, Chandrakala $\mathrm{S}^{2}$, Narayana $\mathrm{G}^{3}$, Karthik $\mathbf{N ~ M}^{4}$ \\ ${ }^{1}$ Post Graduate Student, Department of Civil Engineering, SJCIT, Karnataka, India \\ ${ }^{2}$ Assistant Professor, Department of civil engineering, SJCIT, Karnataka, India \\ ${ }^{3}$ Head of the Department, Department of civil engineering, SJCIT, Karnataka, India \\ ${ }^{4}$ Assistant Professor, Department of civil engineering, CMRIT, Karnataka, India
}

\begin{abstract}
The Analysis of the tall building is carried out to find the optimum position of outrigger system and belt truss by using lateral loads. The three dimensional model is considered and designed for the gravity load and placing of first and second position of the outrigger. Considering the design of Wind load is calculated by using IS 875 (Part 3) and Design of Earthquake load is calculated by using code IS 1893(part-1): 2000 in order to achieve reduction in drift, Deflection and story shear. The analysis is done by considering tall vertical irregularity of $30^{\text {th }}$ storey of $7 X 7$ bay for 1 to $10^{\text {th }}$ storey and $7 X 6$ bay $11^{\text {th }}$ to $20^{\text {th }}$ storey and $7 X 5$ Bay $21^{\text {st }}$ to $30^{\text {th }}$ storey.
\end{abstract}

Keywords: vertical irregularities, outrigger, linear static analysis Wind and earthquake load.

\section{INTRODUCTION}

Mankind is always fascinated for Tall building. In Early era the symbol of economic power and leadership is the skyscraper. There has been a demonstrated competitiveness that exists in present mankind to proclaim to have the tallest building in the world.

The design of tall and slender structures is controlled by three governing factors, strength (material capacity), stiffness (drift) and serviceability (motion perception and accelerations), produced by the action of lateral loading, such as wind.

\subsection{Vertical Geometric Irregularity}

According to code Vertical geometric irregularity shall be considered to exist where the horizontal dimension of the lateral force resisting system in any storey is more than 150 percent of that in its adjacent storey (Table 5, Page 18, IS 1893-2002 Part-1).

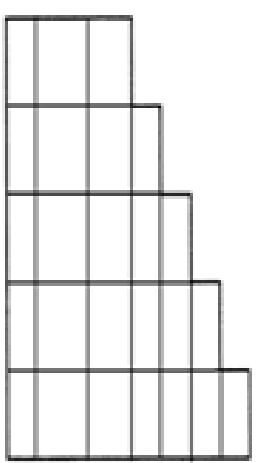

Fig1: Elevation irregularities with abrupt change in geometry

\subsection{Outriggers}

Outrigger beams connected to the core and external columns are relatively more complicated and it is understood that the performance of such coupled wall systems depends primarily on adequate stiffness and strength of the outrigger beam.

The lateral bracing system consisting of core with outriggers is one of the most efficient systems used for high rise construction to resist lateral forces caused by wind and earthquakes.

The integration of the outrigger to the concrete core can be further optimized by guaranteeing concentrated core forces into the outriggers.

This project implements a basic design optimization technique of tall steel structures for lateral loads, mainly wind, into trying to find the optimum locations and number of outriggers for a specific high-rise building. The structure is analyzed for an Earthquake and wind loading.

\section{METHODOLGY}

The three dimensional structure is modeled and designed to the gravity loading such as dead load, live load and floor load. Then place outrigger and belt truss for certain height and check for the drift and deflection.

Fix the first optimum position and vary the second outrigger position and check for the drift and deflection and storey shear. 


\subsection{Details of the Model:}

Table 1: Model Dimensions

\begin{tabular}{|l|l|}
\hline STOREY & DESCRIPTION \\
\hline $1-10$ & $\begin{array}{l}7 \times 7 \text { Bay Spacing } \\
5.5 \mathrm{~m}\end{array}$ \\
\hline $11-20$ & $\begin{array}{l}7 \times 6 \text { Bay Spacing } \\
5.5 \mathrm{~m}\end{array}$ \\
\hline $21-30$ & $\begin{array}{l}7 \times 5 \text { bay Spacing } \\
5.5 \mathrm{~m}\end{array}$ \\
\hline
\end{tabular}

\subsection{Section Properties}

- Beam Details:

Breadth $-230 \mathrm{~mm}$

Depth - $450 \mathrm{~mm}$

- Slab Details: Thickness $-150 \mathrm{~mm}$

Live load $-3 \mathrm{kN} / \mathrm{m}^{2}$

Floor Finish $-1 \mathrm{kN} / \mathrm{m}^{2}$

- Shear Wall: $\quad$ Thickness $-300 \mathrm{~mm}$

- Column Details: $\quad 1^{\text {st }}$ and $2^{\text {nd }}$ storey $800 \times 800 \mathrm{~mm}$ $3^{\text {rd }}$ to $5^{\text {th }}$ storey $700 \times 700 \mathrm{~mm}$

$6^{\text {th }}$ to $10^{\text {th }}$ storey $600 \times 600 \mathrm{~mm}$

$11^{\text {th }}$ to $15^{\text {th }}$ storey $500 \times 500 \mathrm{~mm}$

$16^{\text {th }}$ to $30^{\text {th }}$ storey $400 \times 400 \mathrm{~mm}$

- Outrigger Property: 300 x 300mm with Belt truss

- Concrete Grade: $\mathrm{M}_{40}$.

- $\quad$ Steel: $\mathrm{Fe}_{500}$.

- Wind load: (IS: 875(Part 3) -1987) - Bhuj

Design Speed $-50 \mathrm{~m} / \mathrm{s}$

Terrain Category -3

Class - B

Diaphragms - Rigid

- $\quad$ Earth Quake Load:

(1893(Part 1): 2002) - Bhuj

Zone V - 0.36

Importance factor -1

Type of soil - Medium Soil

Reduction Factor - 5

Mass Source Definition

Dead Load - 1

Floor Finish- 1

Live Load- 0.25

\section{LOAD COMBINATION}

COMBO-1: (DL+LL) x1.5

COMBO-2: (DL+LL+FL) x1.5

COMBO-3: (DL+LL+FL+WL) $\times 1.2$

COMBO-4: (DL+LL+FL-WL) x1.2

COMBO-5: (DL+LL+FL+EQ) x1.2

COMBO-6: (DL+LL+FL-EQ) x1.2

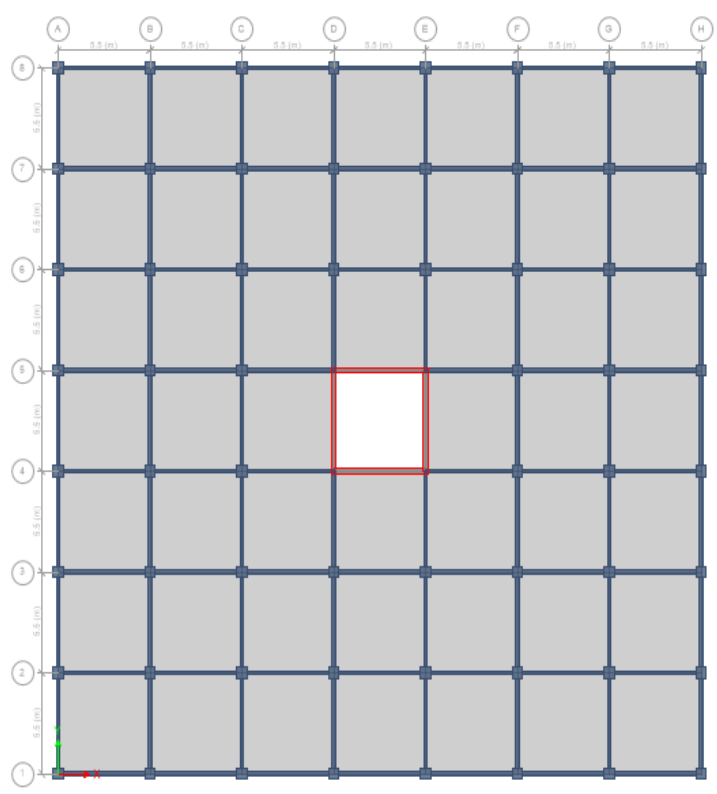

Fig 2: Plan

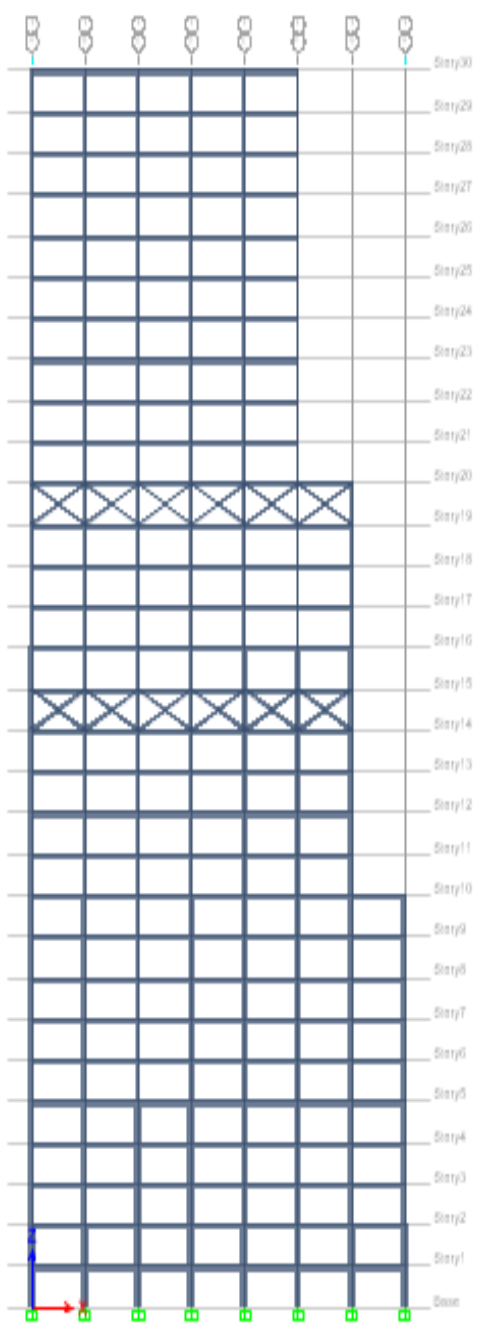

Fig : 3 Elevation of the structure 


\section{RESULTS AND DISCUSSION}

Case 1: Bare Frame Analysis and Design

Case 2: Analysis of Bare Frame with outrigger system for the first optimum location.

- $\quad$ Outrigger with Belt truss at 0.25 Position

- Outrigger with Belt truss at 0.33 Position

- Outrigger with Belt truss at 0.5 Position

- Outrigger with Belt truss at 0.67 Position

- Outrigger with Belt truss at 0.75 Position

- Outrigger with Belt truss at top Position

Case 3: Analysis of Bare Frame with outrigger system for Second position keeping first position common at 0.67 .

- $\quad$ Outrigger with Belt truss at 0.25 Position

- Outrigger with Belt truss at 0.33 Position

- Outrigger with Belt truss at 0.5 Position

- Outrigger with Belt truss at 0.75 Position

- Outrigger with Belt truss at top Position

Table 1: Deflection for the Combo 6

\begin{tabular}{|l|l|}
\hline Outrigger Position & Deflection ,mm \\
\hline 0.25 & 185.7 \\
\hline 0.33 & 179.6 \\
\hline 0.5 & 168.4 \\
\hline 0.67 & 164.9 \\
\hline 0.75 & 169.5 \\
\hline 1 & 192.4 \\
\hline bare frame & 233.8 \\
\hline
\end{tabular}

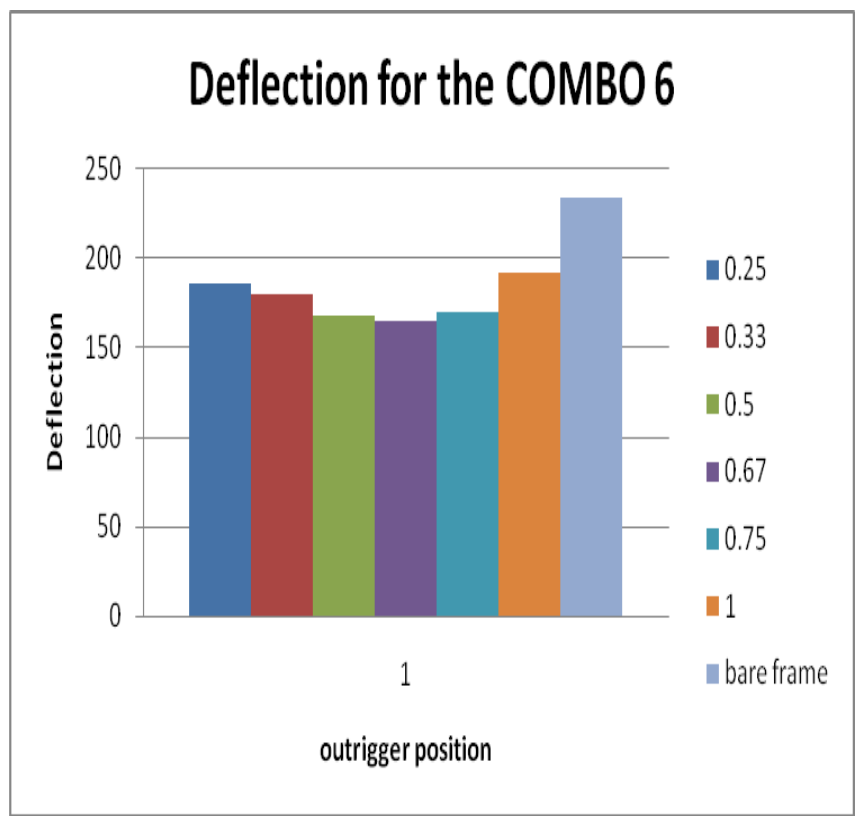

Graph 1: Deflection for Combo 6

Table 2: Deflection for the Combo 5

\begin{tabular}{|l|l|}
\hline Outrigger Position & Deflection ,mm \\
\hline 0.25 & 165.2 \\
\hline
\end{tabular}

\begin{tabular}{|l|l|}
0.33 & 156.7 \\
\hline 0.5 & 143.8 \\
\hline 0.67 & 130.4 \\
\hline 0.75 & 143.8 \\
\hline 1 & 164.2 \\
\hline bare frame & 206.9 \\
\hline
\end{tabular}

From the deflection graphs we use to get combo5 as the critical position and optimum position is $0.67 \mathrm{H}$

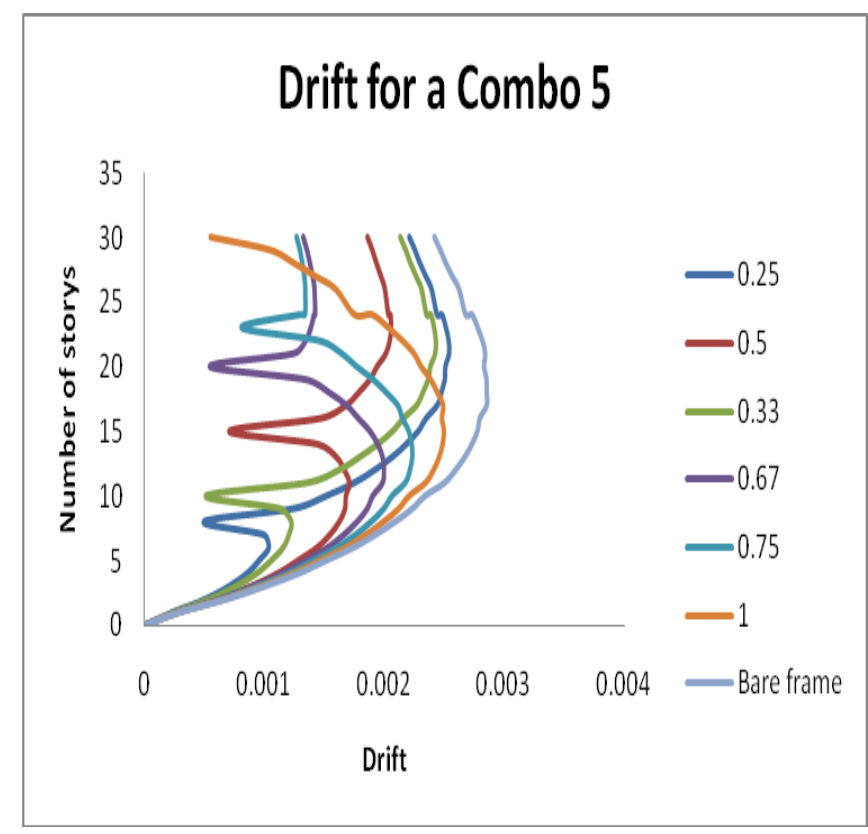

Graph 2 : Drift for Case1 and case2

Table 3: Story Shear for Case 1 and Case2

\begin{tabular}{|c|c|c|}
\hline & & $\begin{array}{l}\text { Base } \\
\text { Shear } \\
(\mathrm{kN})\end{array}$ \\
\hline \multicolumn{2}{|c|}{ Bare frame } & 7501.437 \\
\hline \multirow{6}{*}{ 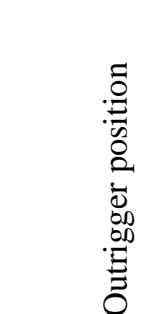 } & 0.25 & 7544.49 \\
\hline & 0.33 & 7659.824 \\
\hline & 0.5 & 7791.578 \\
\hline & 0.67 & 7541.178 \\
\hline & 0.75 & 7537.866 \\
\hline & 1 & 7537.866 \\
\hline
\end{tabular}




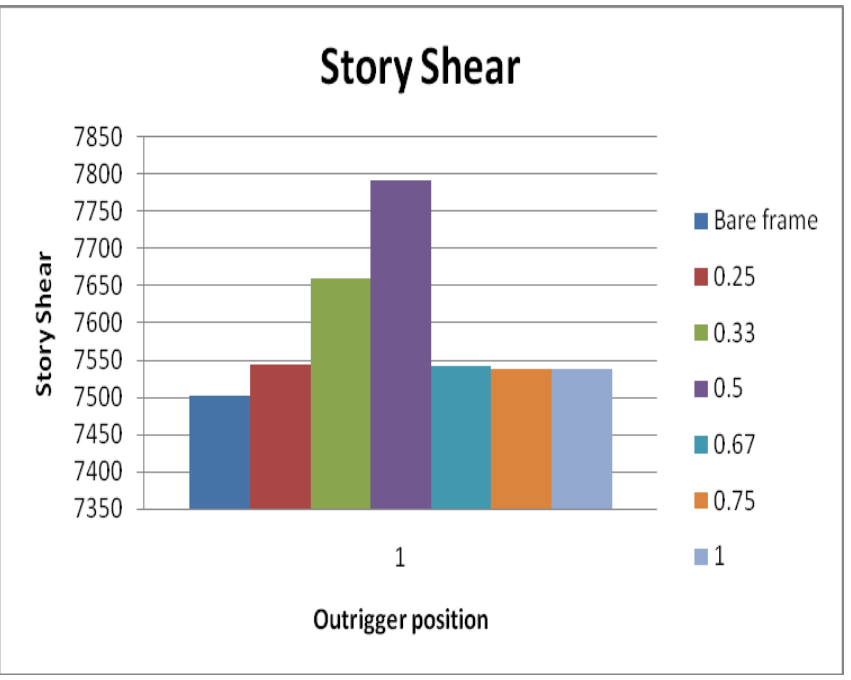

Graph 3 : Story Shear for Case1 and Case 2

Table 4 : Deflection for Case1, Case2 and case3

\begin{tabular}{|l|l|}
\hline $\begin{array}{l}\text { Outrigger } \\
\text { Position }\end{array}$ & $\begin{array}{l}\text { Deflection } \\
\text {,mm }\end{array}$ \\
\hline 0.25 & 119.4 \\
\hline 0.33 & 115.6 \\
\hline 0.5 & 113.4 \\
\hline 0.75 & 112.1 \\
\hline 1 & 114.1 \\
\hline $\begin{array}{l}\text { bare } \\
\text { frame }\end{array}$ & 206.9 \\
\hline
\end{tabular}

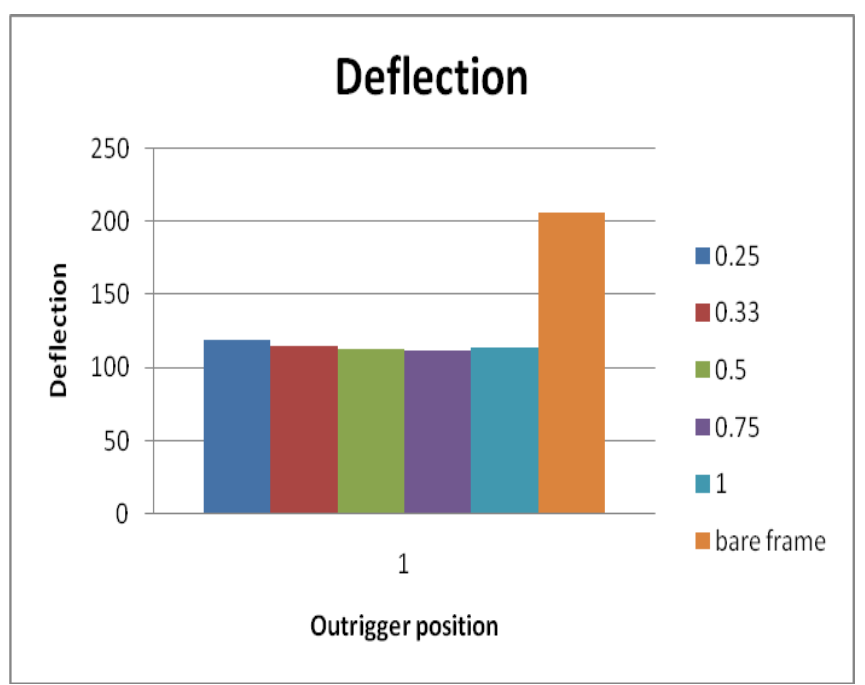

Graph 4 :Deflection for Case1, Case 2 and Case 3

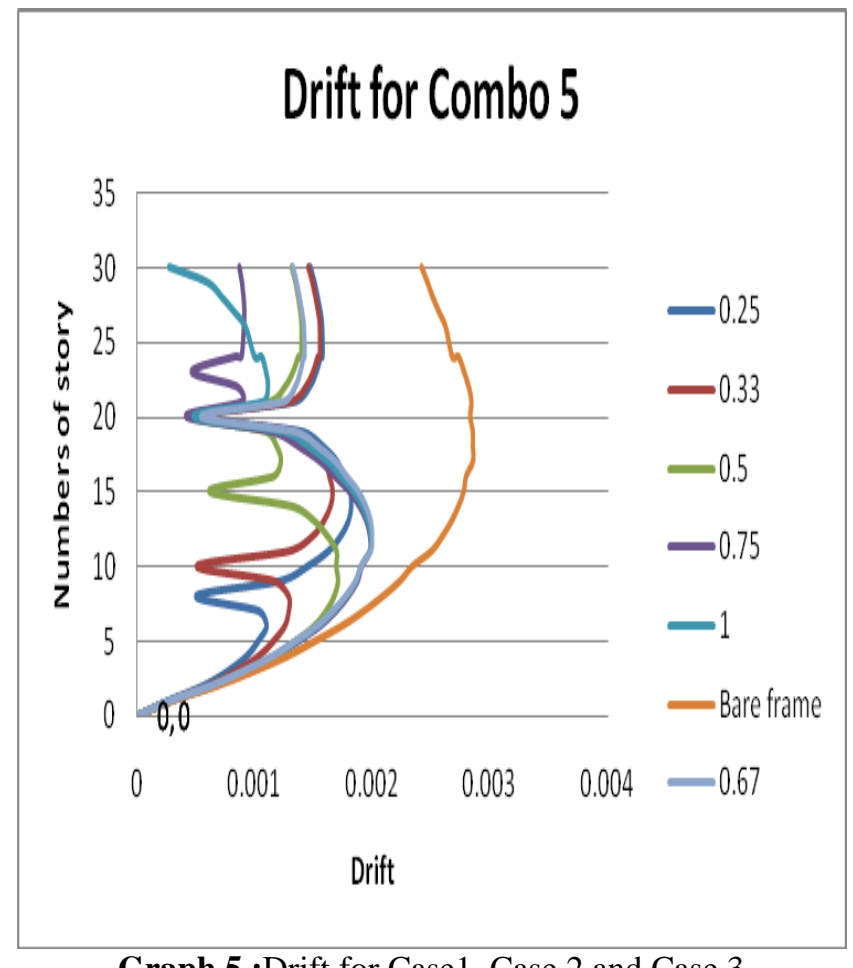

Graph 5 :Drift for Case1, Case 2 and Case 3

Table 5: Story Shear for Case1, Case 2 and Case 3

\begin{tabular}{|c|c|c|}
\hline \multicolumn{2}{|c|}{ Structure type } & $\begin{array}{l}\text { Base } \\
\text { Shear } \\
(\mathrm{kN})\end{array}$ \\
\hline \multicolumn{2}{|c|}{ Bare frame } & 7501.437 \\
\hline \multirow{6}{*}{ 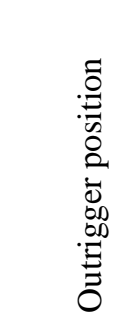 } & 0.25 & 8780.646 \\
\hline & 0.33 & 8936.549 \\
\hline & 0.5 & 8585.365 \\
\hline & 0.75 & 7840.687 \\
\hline & 1 & 7671.84 \\
\hline & 0.67 & 7541.178 \\
\hline
\end{tabular}

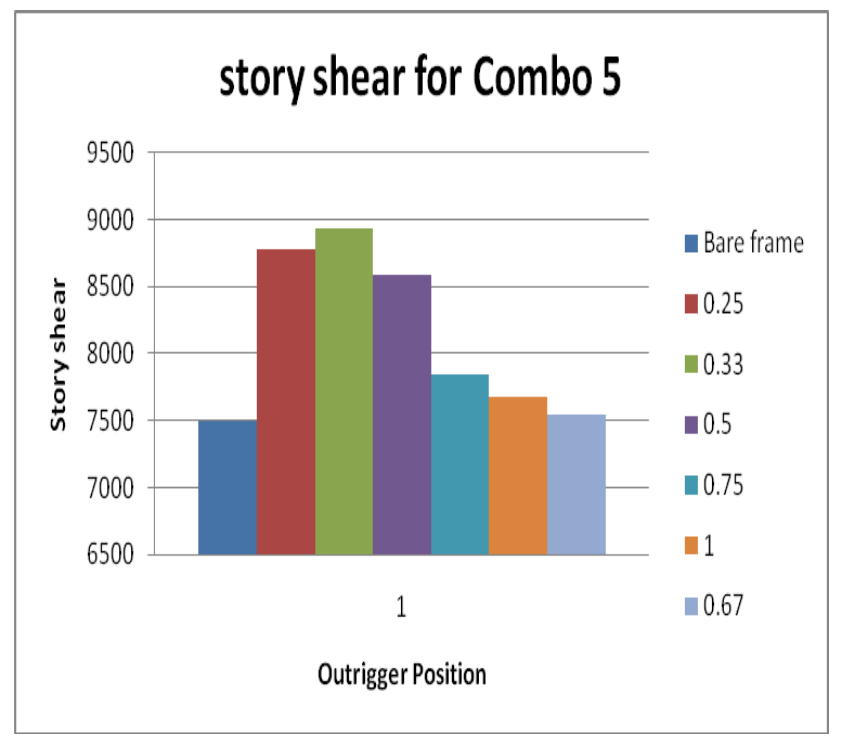

Graph 6 : Story Shear for Case1, Case 2 and Case3 


\section{CONCLUSION}

The most significant basic parameter monitored throughout the whole analysis process was drift and deflection of the building. The following fig 7 and fig 8 shows the variation of drift and deflection: It is observed that $29.8 \%$ and $36.9 \%$ of the deflection and drift is controlled by providing one position outrigger at 0.67 height compared to bare frame. $45.1 \%$ and $40 \%$ of the Deflection and drift is controlled by providing outrigger with belt truss at 0.67 and 0.5 when compared with bare frame. $13 \%$ and $14.64 \%$ of the deflection and drift is controlled by comparing first position outrigger system and second position of outrigger system of the building.

The following conclusions are made from the present study

1- The use of outrigger and belt truss system in highrise buildings increase the stiffness and makes the structural form efficient under lateral load.

2- The maximum drift at the top of structure when only core is employed is around $206.9 \mathrm{~mm}$ and this is reduced by suitably selecting the lateral system. The placing of outrigger at 0.67 height is $130.4 \mathrm{~mm}$.

3 - Using second outrigger with $0.67 \mathrm{~h}$ gives the reduction of $16.64 \%$ and $13 \%$ for drift and deflection. The optimum location of second outrigger is middle height of the building.

4- It can be conclude that the optimum location of the outrigger is between 0.5 times its height.

5- For the second optimum position of outrigger base shear is significantly high compared to first optimum position and bare frame with shear wall.(fig 12) shear wall stress and axial load in the columns to the opposite side of the earthquake direction.

\section{REFERENCES}

[1] Shivacharan K, Chandrakala $\mathrm{S}$ and Karthik N M(2015) "Optimum Position of Outrigger System for tall vertcal irregularites"

[2] P.M.B. Raj Kiran Nanduri, B.Suresh, MD. Ihtesham Hussain (2013) "Optimum Position of Outrigger System for High-Rise Reinforced Concrete Buildings Under Wind And Earthquake Loadings"

[3] Mohd Irfan Moinuddin\& Mohd Afroz Khan Conducted (2013)“A Study for the Optimum Location of Outriggers for High-Rise Concrete Buildings".

[4] Gerasimidis S., Efthymiou E. \& Baniotopoulos C. C. (2009) "Optimum outrigger locations of high-rise steel buildings for wind loading".

[5] N. Herath, N. Haritos, T. Ngo \& P. Mendis (2009) "Behaviour of Outrigger Beams in High rise Buildings under Earthquake Loads".

[6] Karthik.N.M, N.Jayaramappa (December 2014)"optimum position of Outrigger system for High Raised RC Buildings using etabs 2013.1.5 (push over analysis)".

[7] WIND LOAD (IS: 875(Part 3) -1987).

[8] EARTHQUAKE LOADS (1893(Part 1): 2002).

\section{BIOGRAPHIES}

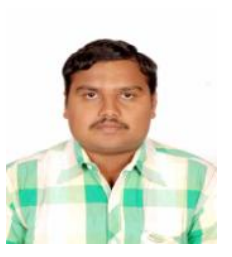

Mr Shivacharan K, Pursuing Final year Mtech in SJC institute of Technology Chickbalapur. Completed My Under Graduation In CBIT Kolar Under VTU.

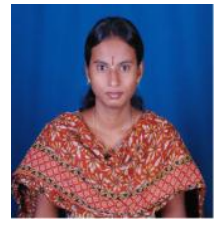

Field.

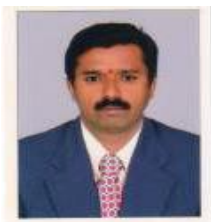

Dr. NARYANA G, Professor and Head Of Department, Department of Civil Enginerring SJC Institute of Technologychickballapur. He had very wide experience of Teaching and Research in the Field of Structural Engineering, also a Structure designed Consultant for many Projects.

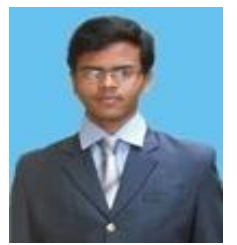

N.M. KARTHIK, Asst Prof, CMR Institute of Technology-Bangalore. Worked as a lecturer for 2 years, as an assistant professor 2 years, experience in design field for a year, Guided 5 post graduation students, 24 under graduation students for their project and dissertation as Asst Prof with 2 journal publications. 